\title{
Inappropriate diet and obesity based on view of the student population
}

\author{
1Pavle Simić, 2Slađana Stanojević \\ ${ }^{1}$ Student II year of the bachelor studies of the \\ Faculty of Agriculture, University of Belgrade, \\ module: Technology of conservation and \\ boiling; Institute of Food Technology and \\ Biochemistry \\ 2 Faculty of Agriculture, University of Belgrade, \\ Institute of Food Technology and Biochemistry \\ Corresonding author: \\ Slađana Stanojević \\ Faculty of Agriculture, University of Belgrade, \\ Institute of Food Technology and Biochemistry; \\ Nemanjina 6, 11080 Zemun; P.O.Box 14, Srbija. \\ Tel./Fax: +381 112199711 . \\ E-mail adress: sladjas@agrif.bg.ac.rs \\ Received 04 May 2020 \\ Accepted 19 June 2020
}

\begin{abstract}
In accordance with their obligations in college, students spend most of their days outside the home. It can lead to irregular and improper diet. The student population tends to consume high-energy, nutrient-poor foods, as well as neglecting meals, usually breakfast. This results in an increasing number of young people who have body-weight problems. The aim of this research was to determine students' attitudes about diet that can lead to obesity, as well as informing students about the consequences of obesity. There were 56 students of the Faculty of Agriculture, University of Belgrade, involved in the study. The research was carried out using anonymous questionnaire. The results of the study showed that a large number of students surveyed considered that they were obese and that obesity was a disease that could be treated in a healthy way. This study suggests that the student population should be offered education in this regard, since most of them are not familiar with the nutritional composition of a food before consuming it, as well as its "body mass index" and "body volume index". On the other hand, the students surveyed are aware of the particular risks that can lead to the onset of obesity, as well as the diseases that can arise as a result of being overweight. In addition, they consider the occurrence of obesity is a major problem not only in the world, but also in Serbia. This research is part of a study entitled "Attitudes and behaviors of students in relation to food and nutrition" and is a form of preventive action to combat the onset of obesity in the student population.
\end{abstract}

Key words: Obesity; Student population; Nutrition; Survey research.

\section{INTRODUCTION}

It is often observed that the student population is not being fed according to contemporary recommendations, standards and guides [1]. In accordance with their obligations in college, students spend most of their days outside of their homes, which often leads to irregular eating and the choice of readily available so-called "fast food" [2]. Fast food, has become a popular choice among students, due to its low cost and convenience [3]. It is well known that changing one's place of living can lead to changes in one's life habits and health. The student population tends to consume high-energy, nutrient-poor food, as well as irregular meals, usually breakfast. Inappropriate eating habits result in an increased number of young people who have weight problems [4]. The obesity of young people, to whom the student population belongs, is a result of their habits and opportunities [5].

Obesity is one of the serious health problems of modern times. It is a multifactorial disorder that is caused by both genetic and environmental factors. Research has shown that the epigenetic mechanisms, that cause obesity, can change during periods of social, technological, and environmental transition [6]. Obesity can cause changes in the physical characteristics of people [7]. Changes in people's bodily characteristics are also likely due to rapid industrial development and the quality of life, new habits and lifestyles [7]. The onset of childhood and adolescence obesity carries the risk of metabolic, endocrine, respiratory and cardiovascular disorders [8]. In addition, obese individuals are often stigmatized because of their obesity and experience discrimination in different settings (for 
example, at employment, as well as at work, at school, in college, in interpersonal relationships). This can lead to the occurrence of psychiatric disorders as well as maladaptive behavior in many domains of daily life [9].

Obesity prevention measures are increasingly common today, because obesity is accompanied by many metabolic disorders and treatment is often time consuming [10]. Numerous studies have shown an inverse association between physical activity and obesity, suggesting that physical inactivity may precede the development of obesity [11]. Increased physical activity, and in particular the avoidance of over-sitting, are crucial for the prevention of obesity as well as for general health [12].

In addition to reduced physical activity, the main cause of obesity is the intake of high-calorie food, mainly rich in sugars and fats. In order to control and prevent obesity in the waistline, as well as associated chronic diseases, it is important to avoid eating high fat or high carbohydrate food [13]. Foods with a high glycemic index, high insulin response, and rapid glucose decline can cause an increase in hunger and lipogenesis. This leads to obesity and a sudden increase of blood sugar. Then, refined carbohydrates also influence the development of chronic diseases [14]. In contrast, carbohydrates from vegetables and fruits reduce the risk of obesity [15].

The challenge that the student population has to go through is the collective diet, organized in canteens. It is an important segment of a healthy diet and is a subject of interest to both educational and healthcare institutions, as well as the whole of society [16]. A large number of students study outside their hometown and away from their families, and because of that a well-organized collective diet is very important to them. The canteen meal is based on hygiene and dietary principles and is a good opportunity to get quality food near their academic activities. Research conducted in Serbia, as well as in other countries, shows that every stay outside the place of residence increases the likelihood of consuming "fast food" $[16,17]$.

About $60 \%$ of a person's body weight is water and water is critical for life; without water, humans can survive only 2-4 days [18]. Motivated by the large number of patients experiencing weight problems in the United States over the last 20 years, researchers recommend water as a beverage for optimal health [19]. Increased water intake has been suggested as a significant way of reducing weight. However, evidence of the efficiency of water in weight loss is limited [20]. It has been found that a higher water intake can reduce the incidence of urinary tract infections [21] and improve glucose regulation for people who have low water intake or elevated copeptin [22].

Providing sufficient energy and nutrients throughout the day is extremely important, and breakfast is considered an important dietary factor for energy regulation [23]. In addition, breakfast is associated with a range of positive outcomes for students, including: better attendance, academic performance, nutrient intake, physical fitness, and weight maintenance $[24,25]$. Omission of breakfast is associated with adverse effects on cognitive and school performance, attendance, psychosocial function, and mood in children and young people $[25,26]$. By omitting breakfast, energy intake is reduced, leading a higher total energy intake during the day, while the nutrients that would be consumed at breakfast are hardly replenished during the day [27].

Obesity is one of the leading health problems in the world, as well as in Serbia. According to data from the $2006,18.3 \%$ of the Serbian population were obese, and the results from the 2013 survey indicate a trend of increasing obesity rates to $21.2 \%$ [28]. Due to the great importance of the obesity problem in Serbia, in 2018 the Government of the Republic of Serbia adopted the National program for the prevention of obesity in children and adults [28].

The literature available to us does not contain data on the attitudes of the student population in Serbia regarding obesity and wrongful diets. The aim of this paper was to determine the views of students at the Faculty of Agriculture, University of Belgrade, on dietary patterns that can lead to obesity, as well as to inform students about the consequences of obesity. This research may be one of the prevention measures for the occurrence of obesity in the student population.

\section{MATERIAL AND METHODS}

The study was conducted using anonymous questionnaires. The survey was done by 56 students on their second year of the bachelor studies at the Institute of Food Technology and Biochemistry, Faculty of Agriculture, University of Belgrade (33 female and 23 male subjects). The students surveyed were selected at random; all students on the second year of the bachelor studies at the Institute of Food Technology and Biochemistry had an equal chance of being selected for the sample. This research is a part of a broader study titled "Attitudes and behaviors of students concerning food and nutrition" conducted among students of the Faculty of Agriculture, University of Belgrade, on the subject of "Food Biochemistry".

Descriptive statistics methods were used to process and analyze the data. Version 8.0 software (StatSoft Co., Tulsa, Oklahoma, USA) was used for statistical processing of the results.

\section{RESULTS AND DISCUSSION}

The self-criticism of the student population regarding obesity was very pronounced. This was indicated by 
the large number of students surveyed who considered themselves obese (67.9\%). Although a relatively significant number of respondents wrongly think that obesity is a consequence of only the wrong nutrition $(28.6 \%)$, most are not familiar with the nutritional composition of the food before consuming it (60.7\%); so many $(75 \%)$ do not pay attention to the intake of macronutrients when consuming food (Figure 1). Students' inattention to the nutritional composition of foods before use indicates that they are not aware of the fact that a high-fat or high-carbohydrate diet can lead to obesity and related chronic diseases [13].

Obesity not only affects the health of individuals, but can also lead to psychiatric disorders, as well as misbehavior in many domains of daily life. Overweight individuals often experience discrimination in different settings [9]. The results of this study indicate that a large number of respondents (53.3\%) were witnesses and as many as $26.3 \%$ were victims of bullying due to obesity (Figure 1). Obesity prevention measures are increasingly common today [10], which is in line with the students' view that obesity can be cured in a healthy way (93.8\%).

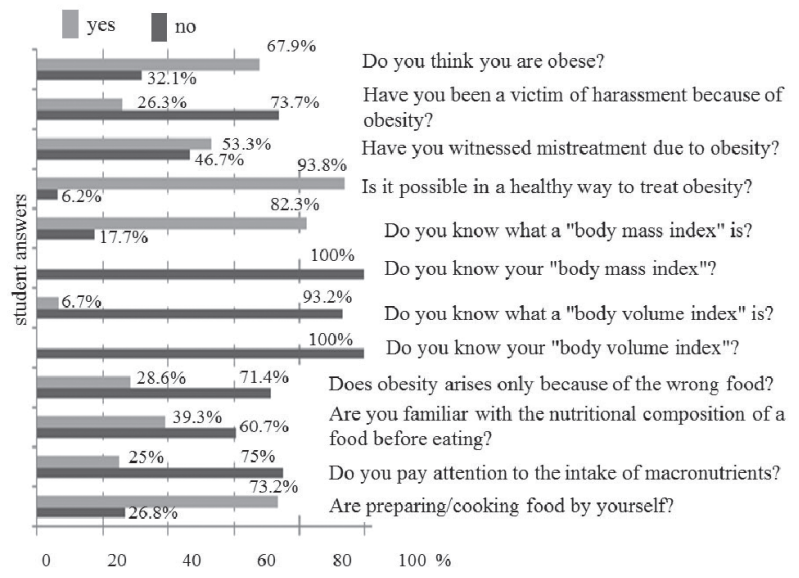

Figure 1. Results of the students' answers to questions related to basic awareness of obesity and their interest in the foods they consume.

The majority of respondents (82.3\%) were familiar with the term „Body Mass Index" (BMI), which is an indicator of body fat content and is based on a person's height and weight [weight (kg) / height (m2)]. According to the World Health Organization, we can differentiate people based on BMI on: underweight (BMI $\left.<18.5 \mathrm{~kg} / \mathrm{m}^{2}\right)$, normal weight $\left(\mathrm{BMI}=18.5-24.9 \mathrm{~kg} / \mathrm{m}^{2}\right)$, overweight $\left(\mathrm{BMI}=25-29.9 \mathrm{~kg} / \mathrm{m}^{2}\right)$, and obese $(\mathrm{BMl}>$ $30 \mathrm{~kg} / \mathrm{m}^{2}$ ) [29]. Obesity is one of the leading health problems that have a significant impact on reducing life expectancy, especially for young people. It is estimated that the reduction of life expectancy is 9-13 years for men over 20 whose BMI is $\geq 35 \mathrm{~kg} \mathrm{~m}^{2}$ [29]. However, respondents did not account BMI (100\%). These tests are related to the "Body Volume Index" $(\mathrm{BVI})$, which shows the difference between individu- als of the same BMI by assessing the distribution of fat through different parts of the body and thus differentiating body shapes. Unlike BMI, students were not aware $(93.2 \%)$ of the meaning of BVI, so they did not account for this index either (100\%; Figure 1).

Many young people have problems with weight due to poor eating habits [4]. The student population tends to consume high-calorie, nutrient-poor foods, as well as omit meals, usually breakfast. The results of the study show that $50 \%$ of students have three meals, $33.9 \%$ of students have more than 3 meals, while $16.1 \%$ of respondents have two meals during the day (Figure 2). This indicates that students generally have regular meals throughout the day. Breakfast is considered an important dietary factor for regulating daily energy [23]. The surveyed students mostly (78.6\%) have breakfast from 9-11 hours, $19.6 \%$ do not have a fixed time when they have breakfast, while a small number of the students (1.8\%) do not have a regular breakfast (Figure 2). Also, dinner is a fixed meal for most of the students (83.9\%) in the period of 19-21 hours, $10.7 \%$ of the respondents have dinner, but not at a regular time during the day, while $5.4 \%$ of students do not have dinner (Figure 2).

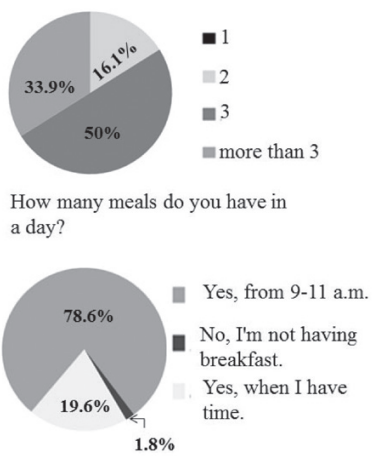

Do you have breakfast and when?

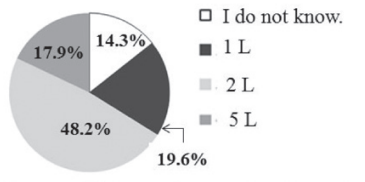

Do you drink enough water in a day and what is the amount?

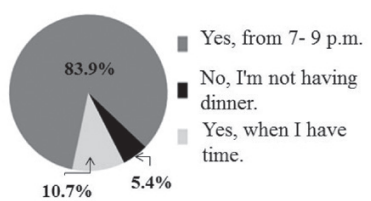

Do you have dinner and when?
Figure 2. Results of the students' answers to questions related to their daily eating habits.

Eating habits of students are a result of their habits and abilities [5], as confirmed by the results of this study. Namely, students consider eating healthy as much as they can (62.5\%), while a relatively large number of respondents (30.4\%) ignore nutritional recommendations and generally consume "comfort foods" (Figure 3). Only a small number of respondents (3.6\%) always check the quality of the foods they consume. Students of the Faculty of Agriculture on Belgrade University have the opportunity to eat in the student canteen, as an important segment of a healthy diet. However, despite the ability to eat in the canteen, students stated that they most often eat at home (82.1\%; Figure 3) and prepare food themselves (73.2\%; Figure 1), while fewer students eat at the canteen $(10.1 \%$; Figure 3). 


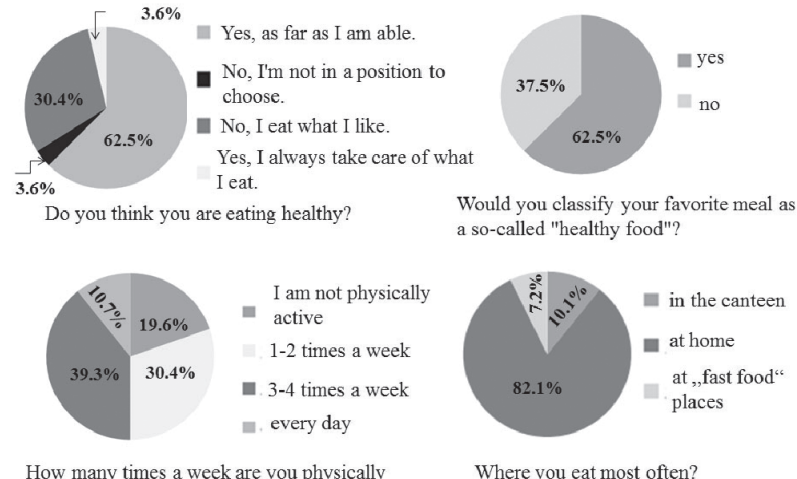

How many times a week are you physically active?

Figure 3. Results of the surveyed students' answers to questions related to attitudes and habits that may be relevant for the onset of obesity.

Literature data indicate that so-called "fast food" is a popular choice among students [3], only partly confirmed by the results of this study (7.2\%; Figure 3 ). However, as many as $62.5 \%$ of the students surveyed consider their favorite foods to be in the "healthy food" group (Figure 3). This was confirmed by their statements of the frequency of eating certain foods. Namely, although a large number of respondents answered that they sometimes prefer to eat barbecue $(76.8 \%)$, pizza (85.7\%) and baked goods, pasta and sweets $(\sim 50 \%)$, nevertheless the main choice is cooked food (80.4\%; Figure 4).

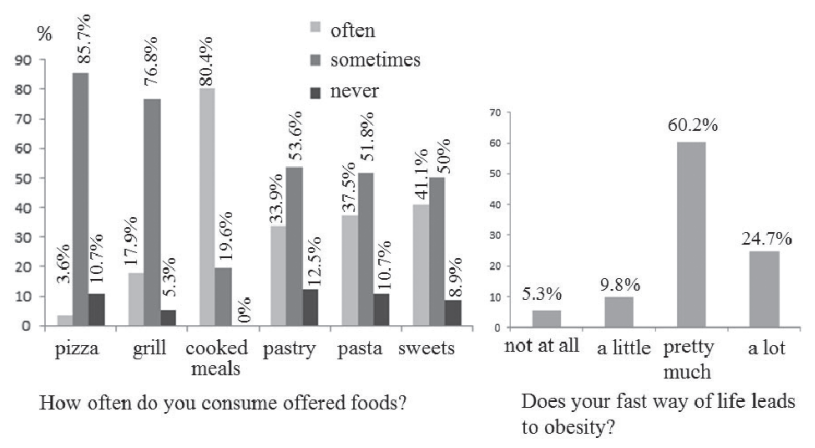

Figure 4. Results of the students' answers to questions related to established habits of consumption of particular groups of nourishment and ways of daily activities that can lead to obesity.

Researchers recommend water as a beverage for optimal health [19], especially for people who have weight problems. About $60 \%$ of a person's body weight is water and is critical to life because without water, humans can survive only 2-4 days [18]. Survey results show that students are aware of the importance of consuming water. Namely, the daily water intake of most students is $2 \mathrm{~L}(48.2 \%)$, while a certain number of students (14.3\%) said that they did not know their daily water intake (Figure 2).

Most of the students surveyed considered their fast pace of life to be one of the causes of obesity $(60.2 \%$; Figure 4). This is in line with research indicating that rapid industrial development, changes in the quality of life, new habits, and lifestyles may be causes of obesity [7]. Increased physical activity, and particularly the avoidance of over-sitting, is of paramount importance for the prevention of obesity as well as general health [12]. The results of our research showed that $19.6 \%$ of students do not engage in physical activity, while $30.4 \%$ of students are physically active $1-2$ times a week, $39.4 \%$ of students are physically active $3-4$ times a week and $10.7 \%$ of respondents are physically active every day (Figure $\mathbf{3}$ ). The World Health Organization [11] recommends physical activity of at least 150 minutes of moderate to intense physical activity or 75 minutes of vigorous physical activity per week. The results indicate that students comply to these recommendations and that their physical activity is at an enviable level.

Obesity is a risk factor for many chronic non-communicable diseases, such as: type 2 diabetes mellitus, cancers, endocrine, respiratory and cardiovascular disorders; this results in an increase in mortality rates worldwide $[8,30]$. The results of the study show that few students do not know (10.75) the potential diseases that can be caused by obesity (Figure 5B). In addition, students are aware that malnutrition, cease of cigarette smoking, genetic predisposition, insufficient physical activity and various diseases can be causes of obesity (58.2\%; Figure 5D).
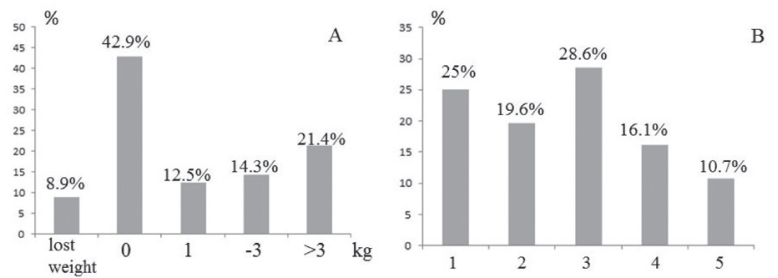

How much weight have you gained in the last 6 Witch diseases can be caused by obesity?
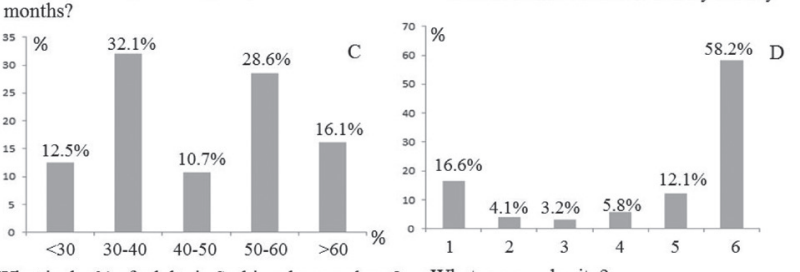

What is the \% of adults in Serbia who are obese? What causes obesity?

Figure 5. Results of the surveyed students' answers to questions related to the occurrence of obesity. B - 1-diabetes, 2-thyroid disease, 3-hypertension, 4-heart disease, 5-I don't know.

D - 1-wrong nutrition, 2-quit smoking, 3-genetic predisposition, 4-different diseases, 5-physical inactivity, 6-all of the above.

Variations in body weight are a common occurrence in the student body, since the student population is most often not fed according to contemporary recommendations, standards and guides [1]. However, the largest number of respondents (42.9\%; Figure 5A) is at a stable weight, while a certain number of students lost weight (8.9\%). Nevertheless, $48.2 \%$ of the 
students surveyed gained weight $-1 \mathrm{~kg}(12.5 \%), 2$ to $3 \mathrm{~kg}(14.3 \%)$ or more than $3 \mathrm{~kg}(21.4 \%)$.

The modern way of life and urbanization are becoming more pronounced in our country as well. The urban population is increasingly oriented towards sedentary lifestyles and work. This is also intensified by the increasing degree of motorized transport, unplanned and uncontrolled urban settlement and reduced opportunities for regular daily physical activity at home, school and professional (work) environment [28]. Unless decisive action is taken in order to reduce the prevention and treatment of obesity, it is predicted that by $2025,50 \%$ of the world's population will be obese [29]. While about thirty years ago, in certain parts of the Republic of Serbia, especially in some underdeveloped rural areas, nutritional deficiencies were a common occurrence, today we rarely see people with clinical signs of nutritional deficits. According to a 2013 survey that estimated that $21.2 \%$ of Serbia's population is obese, the trend is increasing today [28]. The surveyed students consider that the problem of obesity is very prevalling in Serbia; most of them (32.1\%) think that $30-40 \%$ of adults in Serbia are obese.

\section{CONCLUSION}

The results of this study show that although a large number of students surveyed consider themselves obese, most of them do not familiarise themselves with the nutritional composition of the food before consuming it. In addition, no interest was observed in the calculation of "body mass indexes" and "body volume indices", which are one of the relevant indicators of body fat content and distribution. This result suggests that the student population should be offered education in this regard. On the other hand, the students surveyed are aware of the particular risks that can lead to obesity, as well as metabolic disorders and the diseases that can result from being overweight. Observed students believe that obesity is a big problem not only in the world, but also in Serbia. This research is a good way of preventing obesity in the student population.

\section{ACKNOWLEDGMENT}

"The authors thank the students for their participation in this research. Funding for this study was provided by the Ministry of Education, Science and Technological Development of the Republic of Serbia (Grants no. 451-03-68/2020-14/200116)."

\section{REFERENCES}

1. Hot $N$, Jašić $M$, Osmančević $S$. Konzumiranje namirnica koje mogu imati nepovoljne učinke na zdravlje kod studentske populacije na Univerzitetu u Tuzli. "Peti međunarodni simpozijum - Hranom do zdravlja". TuzlaTrondheim-Osijek-Novi Sad-Štip 2012; 40.
2. Đurić D, Mirković M, llić A, Ilić D, Ćorac A, Milošević J. Diet and physical activity habits of student population. Praxis medica 2013; 42(2):33-9.

3. Schwartz MB, Brownell KD. Actions necessary to prevent childhood obesity: creating the climate for change. The Journal of Law, Medicine \& Ethics 2007; 35(1):78-89.

4. Banožić $M$, Ljubić $A$, Pehar $M$, lštuk J, Čačić-Kenjerić $D$. Prehrambene navike studenata Sveučilišta u Mostaru. Hrana u zdravlju i bolesti 2015; 4(2):105-12.

5. Ilić-Živojinović JB. Analiza povezanosti socio-ekoloških faktora i akademskog stresa sa mentalnim zdravljem studenata. Doktorska disertacija, Univerzitet u Beogradu, Medicinski fakultet 2015.

6. Demerath EW. The genetics of obesity in transition. Collegium antropol 2012; 36(4):1161-8.

7. Soljačić Vraneš $H$, Gall V, Jukić $M$, Vraneš Z. Secular changes in growth and obesity in perinatal population. Collegium antropol 2012; 36(2):549-54.

8. Rakić R, Pavlica T, Jovičić D. Overweight and obesity in children and adolescents from Serbia in the period 2001-2004 and 2011-2014. Anthropol Anz 2016; 73(2):109-16.

9. Puhl MR, King MK. Weight discrimination and bullying. Best Pract Res Clin 2013; 27:117-27.

10. WHO (World Health Organization). Obesity: preventing and managing the global epidemic 2000; No. 894.

11. WHO (World Health Organization). Global recommendations on physical activity for health. WHO Library Cataloguing-in-Publication Data 2010.

12. Saris WHM, Blair SN, Van Baak MA, Eaton SB, Davies PSW, Di Pietro L, et al. How much physical activity is enough to prevent unhealthy weight gain? Outcome of the IASO 1st Stock conference and consensus statement. Obes rev 2003; 4(2):101-14.

13. Nikbazm R, Rafie M, Ghanebasiri M, Nourshahi N, Sotoudeh $G$, Eshranghian $M$, et al. The relationship between waist circumference and macronutrient intake in patients with type 2 diabetes in Tehran. Intl Res J Appl Basic Sci 2013; 5:1021-4.

14. Ley SH, Hamdy O, Mohan V, Hu FB. Prevention and management of type 2 diabetes: dietary components and nutritional strategies. Lancet 2014; 383:1999-2007.

15. Romaguera $D$, Ängquist $L, D u H$, Jakobsen MU, Forouhi NG, Halkjær J, et al. Food composition of the diet in relation to changes in waist circumference adjusted for body mass index. Plos One 2011; 6(8):e23384.

16. Simić B. Medicinska dijetetika. Beograd: IP Nauka; 1998; 340-1.

17. Ayo SA, Bonabana-Wabbi J, Sserunkuuma D. Determinants of fast food consumption in Kampala, Uganda. African Journal of Food, Agriculture, Nutrition and Development 2012; 12(5):6567-81.

18. Daniels MC, Popkin BM. Impact of water intake on energy intake and weight status: a systematic review. Nutr Rev 2010; 68(9):505-21.

19. Popkin BM, Armstrong LE, Bray GM, Caballero B, Frei B, Willett WC. A new proposed guidance system for beverage consumption in the United States. The American journal of clinical nutrition 2006; 83(3):529-542.

20. Wong JM, Ebbeling CB, Robinson L, Feldman HA, Ludwig DS. Effects of advice to drink 8 cups of water per day in adolescents with overweight or obesity: a randomized clinical trial. JAMA Pediatr 2017; 171(5):e170012. 
21. Hooton TM, Vecchio M, Iroz A, Tack I, Dornic Q, Seksek I, Lotan Y. Effect of increased daily water intake in premenopausal women with recurrent urinary tract infections: a randomized clinical trial. JAMA Intern Med 2018; 178(11):1509-1515.

22. Enhörning S, Tasevska I, Roussel R, Bouby N, Persson M, Burri $\mathrm{P}$, et al. Effects of hydration on plasma copeptin, glycemia and gluco-regulatory hormones: a water intervention in humans. Eur J Nutr 2019; 58(1): 315-324.

23. Behrens B. Is breakfast or breakfast skipping associated with adiposity in adults? Methodological considerations. CFS Honors Program Undergraduate Theses 2009; 1.

24. Sandercock GRH, Voss C, Dye L. Associations between habitual school-day breakfast consumption, body mass index, physical activity and cardiorespiratory fitness in English schoolchildren. Eur J Clin Nutr 2010; 64(10): 1086-1092.

25. Hoyland A, Dye L, Lawton CL. A systematic review of the effect of breakfast on the cognitive performance of children and adolescents. Nutr Res Rev 2009; 22:220-243.
26. Rampersaud GC, Pereira M A, Girard BL, Adams J, Metzl JD. Breakfast habits, nutritional status, body weight, and academic performance in children and adolescents. J Am Diet Assoc 2005; 105(5):743-760.

27. Schusdziarra V, Hausmann M, Wittke $C$, Mittermeier J, Kellner M, Naumann A, Wagenpfeil S, Erdmann J. Impact of breakfast on daily energy intake-an analysis of absolute versus relative breakfast calories. Nutr J 2011; 10(1):1-8.

28. Government of the Republic of Serbia. National program for the prevention of obesity in children and adults. 2018; Službeni glasnik RS. 9. in Serbian.

29. WHO (World Health Organization). Obesity: preventing and managing the global epidemic. Report of a WHO Consultation presented at: the World Health Organization 1997; Geneva, Switzerland. Publication WHO/NUT/ NCD/98.1.

30. WHO (World Health Organization) Global health risks: Mortality and burden of disease attributable to selected major risks; 2009; Geneva: WHO.

\section{Stavovi studentske populacije o nepravilnoj ishrani i gojaznosti}

\author{
Pavle Simić, Sladjana Stanojević \\ Poljoprivredni fakultet, Univerzitet $u$ \\ Beogradu, Institut za prehrambenu \\ tehnologiju i biohemiju
}

\begin{abstract}
Kratak sadržaj
U skladu sa svojim obavezama na fakultetu studenti veći deo dana provode van kuće, što može dovesti do neredovne i nepravilne ishrane. Studentska populacija sklona je konzumiranju visokoenergetske hrane siromašne nutrijentima, kao i zanemarivanju obroka, najčešće doručka. Neodgovarajuće navike u ishrani, za posledicu imaju sve veći broj mladih koji imaju problema s telesnom težinom. Cilj ovog istraživanja je bio da se utvrde stavovi studenata o načinu ishrane koji mogu dovesti do pojave gojaznosti, kao i o informisanosti studenata o posledicama gojaznosti. U studiju je uključeno 56 studenata Poljoprivrednog fakulteta, Univerziteta u Beogradu. Istraživanje je sprovedeno pomoću anonimnog upitnika. Rezultati istraživanja su pokazali da veliki broj ispitanih studenata smatra da su gojazni i da je gojaznost bolest koja se može lečiti na zdrav način. Ova studija ukazuje na to da bi studentskoj populaciji trebalo ponuditi edukaciju u ovom smislu, obzirom da većina njih nije upoznata sa nutritivnim sastavom namirnice pre njenog konzumiranja, kao ni sa svojim "indeksom mase tela" $i$ "indeksom zapremine tela". Sa druge strane, anketirani studenti su svesni pojedinih rizika koji mogu dovesti do pojave gojaznosti, kao i metaboličkih poremećaja i bolesti koje mogu nastati kao posledica prekomerne težine. Pored toga, smatraju da pojava gojaznosti predstavlja veliki problem ne samo u svetu, nego i u Srbiji. Ovo istraživanje deo je studije pod nazivom „Stavovi i ponašanja studenata u vezi sa hranom $i$ ishranom" i predstavlja vid preventivnih aktivnosti na suzbijanju pojave gojaznosti kod studentske populacije.
\end{abstract}

Ključne reči: Gojaznost; Studentska populacija; Ishrana; Anketno istraživanje. 